
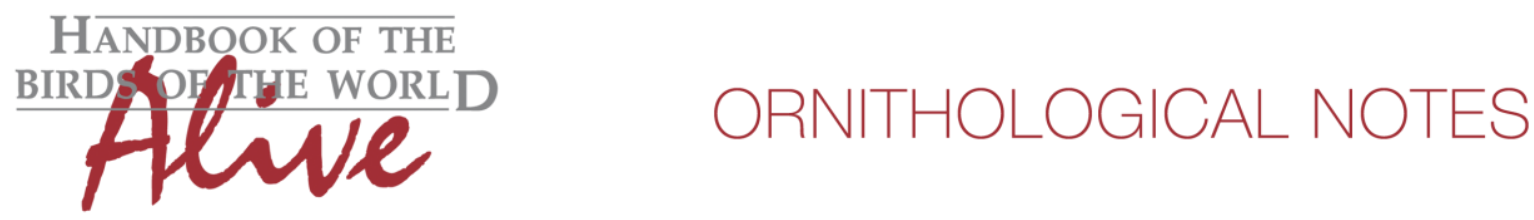

\title{
Notes on the vocalizations of Barred Fruiteater (Pipreola arcuata)
}

Peter Boesman

In the following we briefly analyze and compare voice of both races of Barred Fruiteater (Pipreola arcuata). We also try to quantify the extent of any vocal differences using the criteria proposed by Tobias et al. (2010), as a support for taxonomic review. We have made use of sound recordings available on-line from Xeno Canto (XC).

Barred Fuiteater has two 'song-type vocalisations': a commonly heard fairly short overslurred highpitched whistle, and a less common remarkably long whistle steadily increasing in pitch (the latter only documented for birds from S Ecuador to further south, I assume thus for both races) (Fig. 1).

long whistle

$\begin{array}{lll} & \text { arcuata }(\mathrm{n}=3) & \text { viridicauda }(\mathrm{n}=5) \\ \text { start freq. } & 5500-6200 \mathrm{~Hz} & 5500-6000 \mathrm{~Hz} \\ \text { end freq. } & 8900-10100 \mathrm{~Hz} & 9000-9500 \mathrm{~Hz} \\ \text { length } & 5-5.5 \mathrm{~s} & 4-4.5 \mathrm{~s}\end{array}$

There seems to be a small difference in length of the whistle (although a larger sample size would be needed to prove this is not a pure coincidence).

\section{Short whistle}

$\begin{array}{lll} & \text { arcuata }(\mathrm{n}=5) & \text { viridicauda }(\mathrm{n}=5) \\ \text { min. freq. } & 6000-8000 \mathrm{~Hz} & 6000-7000 \mathrm{~Hz} \\ \text { max. freq. } & 7500-10000 \mathrm{~Hz} & 8000-8500 \mathrm{~Hz} \\ \text { length } & 1.8-2.2 \mathrm{~s} & 2.0-2.5 \mathrm{~s} \\ \text { freq. range } & 1200-2000 \mathrm{~Hz} & 1900-2000 \mathrm{~Hz}\end{array}$

There is considerable overlap in all basic parameters. Note shape is also quite variable for both races, without clear pattern. Apparently no diagnostic differences.

This note was finalized on 10th June 2015 , using sound recordings available on-line at that moment. We would like to thank in particular the sound recordists who placed their recordings for this species on XC: Nick Athanas, Peter Boesman, Meena Haribal, Bennett Hennessey, Sebastian Herzog, Olaf Jahn, Niels Krabbe, Frank Lambert, Dan Lane, Mitch Leisinger, Sjoerd Mayer, John V Moore, Bob Planqué, Andrew Spencer, Joseph Tobias and Herman Van Oosten. 
HANDBOOK OF THE

BIRDAPIVE WORLD ORNITHOLOGICAL NOTES


Figure 1: from top to bottom: example of long whistle of arcuate, viridicauda, short whistle of arcuate, viridicauda.

2 


\section{References}

Tobias, J.A., Seddon, N., Spottiswoode, C.N., Pilgrim, J.D., Fishpool, L.D.C. \& Collar, N.J. (2010). Quantitative criteria for species delimitation. Ibis 152(4): 724-746.

\section{Recommended citation}

Boesman, P. (2016). Notes on the vocalizations of Barred Fruiteater (Pipreola arcuata). HBW Alive Ornithological Note 110. In: Handbook of the Birds of the World Alive. Lynx Edicions, Barcelona. (retrieved from http://www.hbw.com/node/932015 on 2 August 2016). 